\title{
Pendayagunaan Zakat Produktif dalam Meningkatkan Usaha Masyarakat Melalui Program BISA (Bunda Mandiri Sejahtera) Di Yatim Mandiri Surabaya
}

\author{
Sri Wahyuni \\ UIN Sunan Ampel Surabaya \\ e-mail: sri649016@gmail.com
}

\begin{abstract}
Abstrak
Penelitian ini bertujuan untuk menesururi strategi pengelolaan zakat produktif yang dilakukan oleh lembaga amil zakat Yatim Mandiri Surabaya. Signifikankan penelitian ini terletak pada program yang diterapkan oleh lembaga zakat tersebut yaitu program BISA (Bunda Mandiri Sejahtera). Program ini merupakan unggulan sekaligus pembeda dengan pola pengelolaan zakat produktif lainnya. Penelitian ini penting dilakukan mengingat problem pengelolaan zakat produktif masih tersendat dan tidak efektif. Berbagai program yang digalakkan, belum mampu mengangkat derajat lembaga pengelola zakat produktif dapat benar-benar menghasilkan "sesuatu" yang dapat meringangkan ekonomi masyarakat. Penelitian ini merupakan penelitian kualitatif dengan analisis data deskriptif analisis yaitu teknik analisa data yang digunakan dengan cara mendiskripsikan atau memaparkan datadata yang sudah dikumpulkan kemudian di analisis. Setelah dilakukan penelitian dengan metode tersebut, dihasilkan temuan yaitu pengelolaan zakat di Lembaga Yatim Mandiri Surabaya melalui aspek perencanaan, pengorganisasian, pengarahan dan pengawasan untuk mencapai tujuan oragnisasi yang optimal dan penyaluran zakat produktif di LAZNAS Yatim Mandiri yang diberikan kepada para bunda melalui program BISA dalam bentuk modal usaha bertujuan untuk meningkatkan usaha para bunda.. Usaha yang dijalankan para bunda dapat meningkat karena adanya bantuan dari program BISA, walau budget yang diberikan tidak begitu besar namun manfaatnya dapat dirasakan oleh para bunda. Selain itu didalam program BISA terdapat program pembinaan kerohanian yang bertujuan untuk meningkatkan pengetahuan keagamaan para bunda.
\end{abstract}

Keyword: Zakat Produktif, Usaha, Program BISA, Yatim Mandiri Surabaya

\section{Latar Belakang}

Persoalan kemiskinan di Indonesia menjadi momok mengerikan dari tahun ke tahun. Data mencatat jumlah penduduk miskin mencapai 25,14 juta sampai Bulan Maret 2019. ${ }^{1}$ Jumlah ini sangatlah besar jika dibandingkan 
dengan negara-negara lain yang rata-rata tidak mencapai 5 persen dari jumlah penduduk keseluruhan. Standar penentuan penduduk miskin tersebut diambil yang paling rendah dengan skala penduduk yang tidak mampu memenuhi kebutuhan pokoknya.

Kondisi demikian sangat tidak elok bila harus menunggu program negara untuk menyelesaikan. Salah satu lembaga yang bertujuan untuk mengentaskan kemiskinan adalah memaksimalkan peran lembaga amil zakat dengan program dan strateginya. Lembaga zakat pada hakikatnya hanya perposisi sebagai fasilitator atau pengelola, sementara yang memberikan dana sosial adalah para muzakki. Disinilah letak pemberdayaan yang dimaksud, yang mampu mengeluarkan harta kekayaannya berupa dana zakat kepada mereka yang membutuhkan.

Disadari atau tidak, zakat yang diberikan kepada mustahiq dapat berperan bagi peningkatan ekonomi mereka apabila dikelola secara produktif. $^{2}$ Pendayagunaan dana zakat secara produktif sebenarnya memiliki konsep perencanaan dan pelaksanaan seperti penyebab kemiskinan, ketiadaan lapangan pekerjaan dan tiadanya modal usaha. Agar dana zakat dapat bergulir secara efektif dan menghasilkan, maka perlu dilakukan perencanaan untuk mengelola dana zakat. ${ }^{3}$

Salah satu pola pengembangan zakat produktif yang telah dilakukan adalah dengan menjadikan dana tersebut sebagai modal usaha mustahiq. ${ }^{4}$ Dengan modal usaha ini, mustahiq dapa memiliki penghasilan sendiri, meningkatkan pendapatan dan mengembangkan usaha dengan tanpa membayar angsuran atau cicilan ke lembaga lain. Inilah yang dimaksud dengan pola pemberdayaan masyarakat melalui pendayagunaan zakat produktif.

Dengan memberikan modal usaha kepada mustahiq, usaha kecil dapat berkembang dan menyerap tenaga kerja, yang berarti angka pengangguran

1 https://www.cnnindonesia.com/ekonomi/20190715132823-532-412205/jumlah-pendudukmiskin-ri-maret-2019-turun-jadi-2514-juta diakses tanggal 14 Agustus 2019.

${ }^{2}$ Arif Kusmanto, "Peran Lembaga Amil Zakat Nasional Dalam Penghimpunan Dana Zakat, Infaq, dan Shodaqoh," Pandecta: Research Law Journal 9, no. 2 (December 1, 2014): hlm. 302., https://doi.org/10.15294/pandecta.v9i2.3581.

${ }_{3}^{3}$ Agustina Mutia, Analisis Faktor-Faktor yang Mempengaruhi Kesejahteraan Ekonomi Mustahik Melalui Pemberdayaan Zakat (Studi Kasus Penyaluran Zakat Produktif/Modal Usaha pada Bazda Kota Jambi). KONTEKSTUALITA, 25 (1) 2009, hlm. 4.

4 Husnul Khatimah, "Pengaruh Zakat Produktif terhadap Peningkatan Kesejahteraan Ekonomi Para Mustahik", Jurnal Ekonomi Keuangan dan Bisnis Islam, 1 (4) 2004, hlm. 87. 
dapat terkurangi. Berkurangnya pengangguran dapat berdampak pada daya beli masyarakat terhadau suatu produk barang atau jasa. Pada gilirannya akan menumbuhkan sektor produksi. Sirkulasi ini menjadi salah satu indikator adanya pertumbuhan ekonomi masyarakat di Indonesia. ${ }^{5}$

Zakat produktif dalam Islam dibolehkan. Seba zakat bertujuan untuk mewujudkan keadilan sosial melaui mekanisme distribusi kekayaan dari orang kaya kepada orang miskin atau keluarga pra sejahtera. Islam mengehendaki agar kekayaan tidak hanya berputar-putar dari keluarga orang kaya. Bahkan secara normatif, Islam memandang bahwa di dalam harta orang-orang kaya terdapat hak orang-orang miskin. ${ }^{6}$ Dengan adanya zakat maka harta orang kaya akan tersalurkan dan dapat dimanfaatkan kepada orang yang lebih membutuhkan.

Dana ZIS sudah di kelola, dihimpun dan disalurkan oleh organisasi Zakat yaitu BAZNAS dan LAZNAS sehingga Muzakki dapat berdonasi dengan mudah dan mustahiq dapat menerima manfaat sesuai dengan kebutuhannya. LAZNAS Yatim Mandiri Surabaya juga melakukan pengelolaan, penghimpunan dan penyaluran untuk mencapai tujuan Lembaga dengan optimal. Yatim Mandiri melakukan penyaluran zakat dengan membuat program-program yang dapat disalurkan dengan baik kepada para mustahik dan orang-orang yang lebih membutuhkan.

Adapun program-program yang ada di yatim mandiri antaranya : program pemberdayaan ekonomi, program kesehatan, program pendidikan dan program kemanusiaan. Dalam program-program tersebut menggunakan model konsumtif dan produktif, baik konsumtif tradisional, konsumtif kreatif dan produktif konvensional maupun produktif kreatif, hal itu dilakukan sesuai dengan kebutuhan dan permintaan mustahik.

Salah satu program yang ada di Yatim Mandiri yaitu program BISA (Bunda Mandiri Sejahtera). Dalam Program BISA ini ada dua kegiatan yang dilaksanakan pertama pembinaan kerohanian yang bertujuan untuk meningkatkan pengetahuan agama para Bunda. Kedua pemberian pinjaman modal usaha bertujuan untuk meningkatkan usaha para bunda. Sasaran dari Program ini yaitu Bunda dari anak yatim (keluarga yatim) yang juga mendapat bantuan dari Lembaga Yatim Mandiri Surabaya.

\footnotetext{
${ }^{5}$ Mila Sartika, Pengaruh Pendayagunaan Zakat Produktif terhadap Pemberdayaan Mustahiq pada LAZ Yayasan Solo Peduli Surakarta. Jurnal Ekonomi Islam La_Riba, II (1) 2008, hlm. 83.

${ }^{6}$ Muhammad Ridwan, Manajemen Baitul Maal Wa Tanwil. Yogyakarta: UII Press, hlm. 190.
} 


\section{Kerangka Teoritis}

\section{Pengelolaan Zakat}

Pengelolaan zakat sudah ditetapkan atau diatur dalam UndangUndang Republik Indonesia Nomer 23 Tahun 2011 tentang pengelolaan zakat. Dalam undang-undang ini dimaksud dengan pasal 1 berbunyi : "pengelolaan zakat adalah kegiatan perencanaan, pelaksanaan dan pengoordinasasian dalam pengumpulan, pendistribusian dan pendayagunaan zakat. ${ }^{7}$

Hal terpenting dalam mengelola zakat adalah cara yang ditempuh dalam menghimpun dan mendayagunakan dana zakat. Hal itu yang menjadi latar belakang pentingnya peraturan perundangan tentang pengelolaan zakat agar organisasi pengelolaan zakat tidak menempuh caranya sendirisendiri. Dalam UU tersebut ditegaskan bahwa lembaga pengelolaan zakat yang ada di Indonesia adalah BAZ yang dikelola oleh negara serta LAZ yang dikelola oleh masyarakat untuk membantu BAZ dalam pengelolaan zakat.

Pengelolaan zakat memerlukan persiapan dan perencanaan yang matang. Semua aktifitas dan faktor-faktor terkait dengan aktifitas tersebut mesti terencana, terorganisir, bahkan terkontrol dan dievaluasi tingkat capaiannya. ${ }^{8}$ Hal ini diperlukan agar pengelolaan zakat dapat dilakukan secara efektif dan efesien. Dalam konteks pengelolaan zakat, tujuan zakat akan tercapai manakala zakat dikelola secara baik berdasarkan prinsipprinsip manajemen. Dengan kata lain, manajemen zakat merupakan perantara bagi tercapainya kesempurnaan pelaksanaan zakat.

Organisasi pengelola zakat merupakan institusi yang bergerak di bidang pengelolaan dana zakat, infaq dan sadaqah. ${ }^{9}$ Sebagai pengelola zakat, lembaga ini memiliki fungsi yaitu; 1) sebagai perantara keuangan. Disini lembaga zakat sebagai amil berperan sebagai penghubung antara pihak muzakki dengan mustahiq. Maka sebagai perantara, amil dituntut menerapkan asas trust (kepercayaan), asas ini merupakan keharusan yang mutlak dibangun. 2) pemberdayaan. Peran ini berupaya mewujudkan cita-cita

\footnotetext{
7 Keputusan Mentri Agama Republik Indonesia Tentang Pelaksanaan Undang-Undang Nomer 23 Tahun 2011 Tentang Pengelolaan Zakat

8 Yoghi Citra Pratama and UIN Syarifhidayatullah Jakarta, "PERAN ZAKAT DALAM PENANGGULANGAN KEMISKINAN (Studi Kasus : Program Zakat Produktif Pada Badan Amil Zakat Nasional)" 1, no. 1 (2015): hlm. 104.

9 Rifqi Muhammad, Akuntansi Lembaga Keuangan Publik Islam. Modul Mata Kuliah. Yogyakarta: FIAI UII, 2006. hlm. 2.
} 
lembaga untuk menjadian harta muzakki lebih berkah dan mustahik lebih sejahtera secara ekonomi. ${ }^{10}$

\section{Pendistribusian Zakat}

Pendistribusian zakat adalah suatu aktifitas atau kegiatan untuk mengatur sesuai fungsi dan manajemen dalam upaya menyalurkan dana zakat kepada mustahik dari pihak muzakki sehingga mencapai tujuan organisasi dengan efektif. Sistem pendistribusian zakat dari masa kemasa mengalami perubahan. Semula zakat disalurkan untuk kegiatan konsumtif namun belakangan ini lebih banyak pemanfaatan dana zakat disalurkan untuk kegiatan produktif. ${ }^{11}$

Sebuah pendistribusian zakat dilakukan untuk mencapai visi dari zakat yaitu terciptanya masyarakat yang tangguh baik dalam bidang ekonomi maupun non ekonomi, untuk mencapai visi tersebut diperlukan misi distribusi zakat yang memadai. Misi yang dicita-citakan bersifat produktif yaitu mendistribusikan zakat kepada para mustahik dengan harapan dapat memunculkan muzakki-muzakki baru. ${ }^{12}$

Pengelolaan dan pendistribusian zakat di Indonesia ada dua macam yaitu distribusi secara konsumtif dan distribusi secara produktif. ${ }^{13}$ Dana zakat yang terkumpul didistribusikan dalam empat bentuk, yaitu :

1. Konsumtif tradisional

Konsumtif tradisional adalah zakat yang diberikan kepada mustahik secara langsung untuk kebutuhan konsumsi sehari-hari seperti beras. Pola ini merupakan program jangka pendek mengatasi masalah umat. ${ }^{14}$

2. Konsumtif kreatif

Konsumtif kreatif adalah zakat yang diwujudkan dalam bentuk barang konsumtif dan digunakan untuk membantu orang miskin

${ }^{10}$ Didin Hafidhuddin, "Peran Strategis Organisasi Zakat Dalam Menguatkan Zakat Di Dunia" 2, no. 1 (2011): hlm. 3.

${ }^{11}$ Siti Zalikha, "Pendistribusian Zakat Produktif Dalam Perspektif Islam," Jurnal Ilmiah Islam Futura 15, no. 2 (February 1, 2016): hlm. 102., https://doi.org/10.22373/jiif.v15i2.547.

${ }^{12}$ Mursyidi, Akuntansi Zakat Kontemporer, (Bandung: PT Remaja Rosda Karya, 2003), 178

${ }^{13}$ Wahyuddin Maguni, "Peran Fungsi Manajemen Dalam Pendistribusian Zakat: Distribusi Zakat Dari Muzakki Ke Mustahik Pada (Badan Amil Zakat) BAZ" 6, no. 1 (2013): hlm. 199.

${ }^{14}$ Ibid., hlm. 101. 
dalam menghadapi permasalahan sosial dan ekonomi yang dihadapinya semisal beasiswa. ${ }^{15}$

3. Produktif konvesional

Produktif konvesional adalah zakat yang diberikan dalam bentuk barang-barang yang dapat berkembang biak atau alat utama kerja, seperti sapi, kambing dan mesin jahit. ${ }^{16}$

4. Produktif kreatif

Produktif kreatif adalah zakat yang diberikan dalam bentuk modal usaha atau kerja sehingga penerima dapat mengembangkan usahanya setahap lebih maju. ${ }^{17}$

\section{Zakat Produktif}

Zakat produktif adalah zakat yang diberikan kepada fakir miskin berupa modal usaha atau usaha lainnya yang digunakan untuk usaha produktif yang mana hal ini akan meningkatkan taraf hidupnya, dengan harapan seorang mustahik akan bisa menjadi muzakki jika dapat menggunakan harta zakat tersebut untuk usahanya. ${ }^{18}$ Zakat produktif merupakan terobosan baru. Zakat yang sebelumnya diberikan dan hanya dikelola secara konsumtif akan dikelola menjadi zakat produktif yang notabennya lebih berguna, apalagi jika dikaitkan dengan kegiatan ekonomi yang terus berkembang dari waktu kewaktu. ${ }^{19}$

Zakat produktif merupakan sebuah mekanisme baru dan merupakan sebuah alternatif solutif Islam untuk menjawab permasalahan sosial ekonomi masyarakat. Penyaluran zakat secara produktif sendiri tidak hanya terdapat pada contoh dari Rasulullah SAW melainkan berawal dari ijtihad para ulama terdahulu. ${ }^{20}$ Secara praktis pembebasan budak dan pemberian modal sudah pernah di contohkan oleh Nabi Muhammad namun tidak berupa zakat. ${ }^{21}$

\footnotetext{
${ }^{15}$ Ibid., hlm. 101.

${ }^{16}$ Ibid., hlm. 102.

${ }^{17}$ Ibid., hlm. 102.

18 Pratama and Jakarta, "PERAN ZAKAT DALAM PENANGGULANGAN KEMISKINAN (Studi Kasus : Program Zakat Produktif Pada Badan Amil Zakat Nasional)," hlm. 100. ${ }^{19}$ Didin Hafiduddin, Zakat Dalam Perekonomian Modern, (Jakarta: Gema Insani Perss, 2009),.2 ${ }^{20}$ Maltuf Fitri, "Pengelolaan Zakat Produktif sebagai Instrumen Peningkatan Kesejahteraan Umat," Economica: Jurnal Ekonomi Islam 8, no. 1 (October 4, 2017): hlm. 156., https://doi.org/10.21580/economica.2017.8.1.1830.

${ }^{21}$ Ibid., hlm. 158.
} 
Zakat boleh disalurkan secara produktif apabila kebutuhan konsumtif para Mustahik sudah terpenuhi, dan pemberian modal usaha untuk zakat produktif harus dapat dikelola dengan profesional agar memperoleh keuntungan.22 Penyaluran zakat produktif di kalangan umat Islam, menoreh pengaruh besar terhadap perwajahan realitas perekonomian dan sosial pada masyarakat kita. Dibuktikan dengan manfaat dari alokasi zakat yang disalurkan secara produktif dibanding konsumtif. ${ }^{23}$

\section{Peningkatan Usaha}

Arti peningkatan menurut Kamus Besar Bahasa Indonesia adalah proses, cara, meningkatkan perbuatan usaha dan sebagainya. ${ }^{24}$ Menurut seorang ahli bernama Adi S, peningkatan berasal dari kata tingkat, yang berarti lapis atau lapisan dari sesuatu yang kemudian membentuk susunan. Tingkat juga dapat berarti pangkat, taraf, dan kelas. Sedangakan peningkatan berarti kemajuan. Kata peningkatan juga dapat menggambarkan perubahan dari kedaan sifat yang negatif berubah menjadi positif. Sedangkan hasil dari sebuah peningkatan dapat berupa kuantitas dan kaulitas. Kuantitas adalah jumlah hasil dari sebuah proses atau dengan tujuan peningkatan. Sedangkan kualitas menggambarkan nilai dari suatu objek karena terjadinya proses yang memiliki tujuan berupa peningkatan. Hasil dari suatu peningkatan juga ditandai dengan tercapainya tujuan pada suatu titik tertentu, dimana saat suatu usaha atau proses telah sampai pada titik tersebut maka akan timbul perasaan puas dan bangga atas pencapaian yang telah diharapkan. ${ }^{25}$

Usaha merupakan sebuah bisnis yang menghasilkan keuntungan tertentu yang dijalankan dengan modal yang digunakan untuk membuat usaha. Harmaizar $\mathrm{Z}$ juga menjelaskan pengertian dari usaha bahwa usaha disebut juga suatu perusahaan yaitu suatu bentuk usaha yang melakukan

${ }^{22}$ Muslihun Muslihun, "Dinamisasi Hukum Islam Di Indonesia Pada Zakat Produktif Dan Wakaf Produktif: Sebuah Studi Perbandingan," Al-Manahij: Jurnal Kajian Hukum Islam 8, no. 2 (January 1, 1970): th., https://doi.org/10.24090/mnh.v8i2.408.

${ }^{23}$ Siti Zalikha, Pendistribusian Zakat Produktif Dalam Perspektif Islam, (Jurnal Ilmiah Islam Futura, 2016), 315

${ }^{24}$ Depertemen Pendidikan Nasional, Kamus Besar Bahasa Indonesia, (Jakarta: Balai Pustaka,2003), 1198

${ }^{25}$ Adi, s. Pemberdayaan, Pengembangan Masyarakat, Dan Intervensi Komunitas (Pengantar Pada Pemikiran Dan Pendekatan Praktis). (Jakarta : Lembaga Penerbit Fakultas Ekonomi Universitas Indonesia, 2003) 
kegiatan secara tetap dan terus menerus dengan tujuan memperoleh keuntungan, baik yang diselenggarakan oleh perorangan maupun badan usaha yang berbentuk badan hukum maupun tidak berebentuk badan hukum, yang didirikan dan berkedudukan disuatu daerah dalam suatu negara. ${ }^{26}$

Usaha apabila diartikan secara general merupakan setiap aktivitas yang dilakukan manusia untuk mendapatkan sesuatu yang diinginkan. Jika diartikan secara khusus, istilah usaha dapat diartikan kedalam banyak makna dan sangat bergantung dengan dimana istilah usaha ini digunakan. Apabila usahanya dibidang bisnis, maka usahanya identik dengan aktivitas bisnis dan apabila usahanya didunia fisika maka usaha tersebut merupakan faktor dari perpindahan dengan gaya.

\section{Metode Penelitian}

Jenis penelitian ini adalah jenis penelitian kualitatif yaitu suatu pendekatan penelitian yang mengahasilkan data diskriptif berupa data-data tertulis atau lisan-lisan dari informan atau prilaku yang dapat diamati ${ }^{27}$. Penelitian ini dilakukan di Lembaga Amil Zakat Yatim Mandiri Surabaya yang berjudul Penyaluran Zakat Produktif yang mengarah pada programprogram yang ada di Lembaga tersebut salah satunya adalah program Bunda Mandiri Sejahtera yang mana program tersebut bertujuan untuk meningkatkan usaha dan pengetahuan keagaaman para mustahik.

Dalam penelitian ini, data yang digunakan bersumber dari : Sumber data primer, yaitu bersumber dari pihak terkait yaitu staff Program maupun Kesekretariatan Lembaga Amil Zakat Yatim Mandiri Surabaya antaranya Bapak Fikri, Bapak Adam, Mbak Lista dan Ibu Yani sebagai pendamping Bunda BISA. Adapun sumber dari mustahik antaranya Ibu Siti Asiah, Ibu Suti Ningsih, Ibu Umu Cholida, Ibu Hariyanti, Ibu Ma'rifah dan Ibu Irta Juarti.

Sumber data sekunder, yaitu data-data bersumber dari dokumen yang didapat dari Lembaga antaranya dokumen annual report profil Lembaga, Visi Misi Lembaga, Program-program Lembaga dan buku-buku yang digunakan untuk mendukung dan melengkapi data primer antaranya buku

\footnotetext{
${ }^{26}$ Harmaizar Z, Menangkap Peluang Usaha, (Bekasi : CV Dian Anugerah Perkasa, 2003), 11-13

${ }^{27}$ Lexy Moleong, Metode Penelitian Kualitatif, (Bandung: Remaja Rosdakarya, 2002), 3
} 
zakat produktif dalam persepektif islam, dasar-dasar manajemen, pengantar hukum zakat dan wakaf, dan lain sebagainya.

Dalam penelitian ini menggunakan teknik pengumpulan data Observasi, Wawancara dan Dokumentasi. Teknik analisis data Teknik analisis data ini menggunakan teknik deskriptif analisis merupakan teknik yang digunakan dengan cara mendeskripsikan atau memaparkan data-data yang sudah dikumpulkan yaitu tentang Program BISA dalam meningkatkan Usaha Bunda melalui pengelolaan dan penyaluran zakat produktif di Lembaga ZIS Yatim Mandiri surabaya, kemudian di analisis tentang teori fungsi manajemen meliputi planning (perencanaan), organizing (pengorganisasian), actuating (pelaksanaan) dan controling (pengawasan) berkaitan dengan Program BISA dalam meningkatkan Usaha Bunda melalui pengelolaan dan penyaluran zakat produktif di Lembaga ZIS Yatim Mandiri Surabaya.

\section{Hasil dan Pembahasan}

\section{Pengelolaan Zakat di Lembaga Yatim Mandiri}

Pengelolaan zakat di Lembaga Yatim Mandiri menerapkan beberapa strategi untuk mencapai dan mewujudkan tujuan Lembaga, yang meliputi fungsi-fungsi manajemen antaranya:

1. Perencanaan (planning)

Perencanaan atau planning yang dilakukan dengan menyiapkan program-program yang dapat dikelola dan dihimpun dengan baik..

2. Pengorganisasian (Organizing)

Pengorganisasian yang dilakukan dengan memberikan tanggung jawab dan wewenang pada setiap program kerja Yatim Mandiri, selain itu dengan adanya penanggung jawab mereka akan melakukan survey terlebih dahulu untuk mengetahui kondisi lingkungan/rumah, ekonomi dan fisik dari sasaran yang nantinya akan diberi bantuan.

3. Pengarahan (Actuating)

Pengarahan yang dilakukan dengan mengarahkan dan memotivasi para bawahannya agar dapat bekerja sama dengan baik sehingga dapat menciptakan kinerja dan hasil yang memuaskan sesuai dengan harapan dan tujuan dari lembaga.

4. Pengawasan (Controlling) 
Setelah melakukan perencanaan, pengorganisasian dan pengarahan maka Yatim Mandiri juga melakukan pengawasan agar kegiatan dapat terlaksana dengan optimal. Pengawasan yang dilakukan Yatim Mandiri yaitu dengan melakukan pengontrolan terhadap laporan bulanan maupun laporan tahunan baik dari laporan kinerja program maupun keuangan.

Pengelolaan ZIS Lembaga Yatim Mandiri melakukan funding (penghimpunan) dan landing (penyaluran). Ada tiga cara strategi penghimpunan (Funding) dana zakat di Yatim Mandiri antara lain: Pertama: layanan ceramah seperti penyuluhan tentang kewajiban membayar zakat, cara membayar zakat dan lain sebagainya. Hal ini dilakukan juga sebagai bentuk silaturrahmi antara donatur dan amil. Kedua: layanan jemput donasi yang dilakukan oleh petugas lapangan atau ZISCO (Zakat, Infaq, Sedekah Consultan) dengan cara mengambil dana zakat kerumah atau ke kantor para donatur.

Hal ini dilakukan untuk memudahkan donatur untuk berdonasi. Ketiga : Lembaga Yatim Mandiri melayani penghimpunan dana corporet melalui via transfer, Yatim Mandiri juga bermitra dengan beberapa Bank seperti Bank BRI, Bank MANDIRI, Bank MANDIRI Syariah, Bank BCA, Bank BNI, Bank Muamalat, Bank Permata Syariah dan lainnya untuk menerima transfer dana zakat dari muzakki. Selain itu yatim mandiri juga melakukan perencanaan untuk menentukan beberapa target yang harus dikumpulkan setiap tahunnya melalui program-program Yatim Mandiri salah satunya program BISA.

\section{Penyaluran Zakat Produktif Dalam Meningkatkan Usaha Melalui Program BISA (Bunda Mandiri Sejahtera) Di Yatim Mandiri Surabaya}

Penyaluran atau pendistribusian yang ada di Lembaga Yatim Mandiri Surabaya juga bertujuan untuk mengoptimalkan produk yang mereka miliki dengan menggunakan program-program yang bersifat konsumtif maupun produktif. Bentuk penyaluran zakat, infaq dan sedekah secara konsumtif yaitu penyaluran ZIS yang bersifat sesaat atau sekali pakai hanya dalam keadaan yang mendesak diantaranya disalurkan kepada anak yatim yang berprestasi, bantuan korban bencana alam, bantuan saat ramadhan dan lainnya. Sedangkan bentuk penyaluran ZIS secara produktif yaitu diberikan dalam bentuk pemberdayaan ekonomi untuk meningkatkan usaha. Misalnya 
pemberian modal usaha yang difokuskan untuk memberdayakan bunda yatim dengan program pelatihan dan pendampingan kewirausahaan, hal ini dilakukan agar ibu dari anak-anak yatim tetap tegar dan semangat dalam mendidik putra-putrinya.

Penyaluran ZIS di Lembaga Yatim Mandiri sudah diberikan sesuai dengan kesepakatan dan kebutuhan Program-Program dan penerima manfaat. Hal ini sudah jelas disampaikan lewat laporan keuangan Lembaga Yatim Mandiri Surabaya. Berdasarkan Total penerimaan Dana ZIS di Lembaga Yatim Mandiri Surabaya pada bulan April Rp. 8.118.326.917. dan terdapat pula surplus bulan sebelumnya sebanyak Rp. 845.626.499. jadi dana yang tersedia pada bulan April Rp. 8.963.953.416. dana tersebut akan disalurkan berdasarkan program-program yang ada di Lembaga Yatim Mandiri Surabaya dan berdasarkan para mustahiq, antaranya, penyaluran pada Program Pendidikan Rp. 2.930.876.300. untuk Program Kesehatan Rp. 896.393.654. Program Kemanusiaan Rp. 5962.389.142. Program Ekonomi Rp. 216.049.568. Program Dakwah Rp. 3.550.770.143. Jumlah Penyaluran Program-Program Rp. 8.156.478.807. dan surplus bulan ini Rp. 807.474.609. adapun penyaluran berdasarkan mustahik yaitu : penyaluran kepada Mustahiq fakir Rp. 349. 132.259. Mustahiq Miskin Rp. 2.334.483.152. Mustahiq Fisabilillah Rp. 3.827.296.954. Mustahiq Amil Rp. 1.645.593.442. Jumlah Penyaluran Berdasarkan Mustahik Rp. 8.156.478.807. Surplus bulan ini Rp. 807.474.609.

Program BISA (Bunda Mandiri Sejahtera) merupakan salah satu program yang bersifat produktif yang mengutamakan bunda dari anak yatim yang dhuafa untuk menjadi anggotanya, usianya kurang lebih 35-60 tahun, yang memiliki semangat untuk berwirausaha. Adanya program BISA (Bunda Mandiri Sejahtera) ini dapat membantu meningkatkan penghasilan dan kesejahteraan keluarga yatim. Dengan adanya pemberian modal usaha dalam program BISA tersebut mereka dapat memenuhi kebutuhan hidup secara berkelanjutan. Di dalam Program BISA ini terdapat dua proker, yaitu proker jangka pendek dan jangka panjang. Program kerja jangka pendek yang ada dalam Program BISA yaitu setiap bulannya mengadakan pembinaan kerohanian, hal ini diadakan agar dapat membantu meningkatkan pengetahuan para bunda tentang agama Islam serta memotivasi mental para bunda untuk bangkit dari keterpurukan karena ditinggal suaminya selain itu yatim mandiri juga memberikan bingkisan 
berupa sembako, sosis atau kornet yang merupakan produk yatim mandiri sendiri dan uang Rp 50.000. Dan Program Kerja jangka panjangnya yaitu Yatim Mandiri memberikan modal usaha, baik set up usaha dan oprasional usaha yang diberikan setiap setahun sekali.

Usaha yang diberikan Yatim Mandiri merupakan usaha kecil-kecilan seperti Usaha Toko kelontong, Usaha Sembako, usaha sayuran dan lain sebagainya. Walau usaha ini tidak begitu besar namun dengan adanya bantuan pinjaman modal usaha dari Lembaga Yatim Mandiri sangat membantu dalam peningkatan usaha dan penghasilan mereka. Awalnya mereka hanya berjualan secara lesehan namun setelah mendapat penambahan modal, sekarang mereka dapat berjualan dengan gerobak dan memiliki tempat berjualan sendiri.

Usaha yang diberikan oleh Lembaga Yatim Mandiri Surabaya berupa modal usaha bergulir (pinjaman) yang nantinya para bunda akan mengembalikan dalam jangka satu tahun. Hal ini dilakukan untuk mengajarkan para bunda bersikap jujur dan mengajarkan mereka mengatur keuangan dengan baik dan benar. Lembaga Yatim Mandiri Surabaya tidak memungut biaya sedikitpun dari hasil usaha para bunda, keuntungan usaha para bunda tersebut 100\% untuk para bunda sendiri. Lembaga Yatim Mandiri memberikan bantuan modal usaha kepada para bunda yang sudah memiliki usaha dan pihak Lembaga hanya memberikan modal untuk penguatan usahanya saja minimal Rp. 750.000 dan maksimal Rp. 1.000.000.

Adapun pendapatan bunda perbulan sebelum dan setelah diberikan pinjaman modal usaha. Hal ini dilakukan untuk mengetahui tingkat kesuksesan Yatim Mandiri dalam menyalurkan ZIS kepada para penerima manfaat. Pendapatan Ibu Hariyati sebelum di beri bantuan Program BISA Rp. 400,000-600,000. Setelah diberi bantuan Program BISA Rp. 900,0001.700,000. Pendapatan Ibu Irta Juarta sebelum diberi Bantuan BISA Rp. 500,000-700,000. Setelah mendapat bantuan Program BISA Rp. 1.700,0002.200,000. Pendapatan Ibu Makrifah sebelum diberi bantuan program BISA Rp. 500,000-700,000 setelah mendapat bantuan program BISA Rp. 900,0001.500,000. Pendapatan Ibu Asiah sebelum diberi bantuan program BISA Rp. 400,000-600,000 setelah diberi bantuan program BISA Rp. 900,000-1.500,000. Pendapatan Ibu Sutiningsih sebelum diberi bantuan Program BISA Rp. 500,000-700,000 setelah diberi bantuan Program BISA Rp. 900,000-1.600,000. Pendapatan Ibu Umu Khalidah sebelum diberi bantuan Program BISA Rp. 
1.000,000-1.300,000 setelah diberi bantuan program BISA Rp. 1.800,000$2.500,000$.

Demikian hasil dari pendapatan para bunda sebelum dan sesudah diberi bantuan dari Program BISA. Jika ditelaah dari sisi positif penyaluran zakat produktif yang diberikan dalam bentuk program BISA memang sangatlah bermanfaat bagi sebagian para bunda yang menerima manfaat tersebut, namun apabila dilihat dari sisi lainnya, ternyata program BISA ini mengalami kemunduran dari jumlah penerima manfaat yang semakin berkurang, yang awalnya program BISA ini disalurkan ketiga Daerah di SurabayaYaitu Daerah Pagesangan, Daerah Ngagel dan Daerah Bendul Merisi, namun sekarang penerima manfaat hanya ada di Daerah Ngagel dan Bendul Merisi, hal ini terjadi karena kurangnya kepedulian pengurus Lembaga Yatim Mandiri terhadap usaha bunda.

\section{Kesimpulan}

Pengelolaan zakat di Lembaga Yatim Mandiri Surabaya, seperti Lembaga pengelolaan zakat pada umumnya yaitu melalui aspek perencanaan, pengorganisasian, pengarahan dan pengawasan untuk mencapai tujuan yang optimal. dan amil di Lembaga yatim mandiri disebut dengan ZISCO (Zakat Infak Sedekah Consultan) yang bertugas untuk menjemput dana zakat baik dirumah maupun dikantor serta berdakwah menyampaikan kepada masyarakat tentang pengertian zakat dan kewajiban dalam berzakat dan lain sebagainya. Dalam pengelolaan zakat di Lembaga Yatim Mandiri Surabaya juga terdapat funding (penghimpunan) dan landing (penyaluran) sebagai pengoptimalan organisasi untuk pencapaian tujuan yang telah ditetapkan Lembaga.

Penyaluran Zakat di Lembaga Yatim Mandiri Surabaya melalui program-program yang telah terlaksana dengan prosentase yang telah ditargetkan salah satunya program pemberdayaan ekonomi dalam peningkatan Usaha yaitu melalui program BISA (Bunda Mandiri Sejahtera). Program BISA ini fokus diberikan kepada para bunda Yatim yang dhuafa tujuan dari adanya program ini untuk mensejahterakan kehidupan keluarga yatim serta untuk memandirikan mereka. Program BISA ini juga termasuk penyaluran zakat yang produktif, sebab penyalurannya tidak sekali pakai akan tetapi dapat berkembang dan dimanfaatkan dalam jangka waktu panjang. Pemberian modal usaha dalam program ini untuk meningkatkan 
usaha para bunda yang dhuafa, seperti usaha kecila-kecilan yaitu usaha sembako, toko kelontong dan lain sebagainya. Selain pemberian modal usaha, program ini juga memberikan pembinaan kerohanian untuk meningkatkan pengetahuan keagamaan mereka.

\section{Daftar Pustaka}

Adi. Pemberdayaan, Pengembangan Masyarakat, Dan Intervensi Komunitas (Pengantar Pada Pemikiran Dan Pendekatan Praktis). (Jakarta : Lembaga Penerbit Fakultas Ekonomi Universitas Indonesia, 2003)

Depertemen Pendidikan Nasional, Kamus Besar Bahasa Indonesia, (Jakarta: Balai Pustaka,2003).

Fitri, Maltuf. "Pengelolaan Zakat Produktif sebagai Instrumen Peningkatan Kesejahteraan Umat," Economica: Jurnal Ekonomi Islam 8, no. 1 (October 4, 2017).

Hafidhuddin, Didin "Peran Strategis Organisasi Zakat Dalam Menguatkan Zakat Di Dunia" 2, no. 1 (2011).

Hafiduddin, Didin. Zakat Dalam Perekonomian Modern, (Jakarta: Gema Insani Perss, 2009).

Harmaizar Z, Menangkap Peluang Usaha, (Bekasi : CV Dian Anugerah Perkasa, 2003).

Khatimah, Husnul. "Pengaruh Zakat Produktif terhadap Peningkatan Kesejahteraan Ekonomi Para Mustahik". Jurnal Ekonomi Keuangan dan Bisnis Islam, 1 (4) 2004.

Kusmanto, Arif. "Peran Lembaga Amil Zakat Nasional Dalam Penghimpunan Dana Zakat, Infaq, dan Shodaqoh," Pandecta: Research Law Journal 9, no. 2 (December 1, 2014).

Maguni, Wahyuddin. "Peran Fungsi Manajemen Dalam Pendistribusian Zakat: Distribusi Zakat Dari Muzakki Ke Mustahik Pada (Badan Amil Zakat) BAZ" 6, no. 1 (2013).

Moleong, Lexy. Metode Penelitian Kualitatif, (Bandung: Remaja Rosdakarya, 2002).

Muhammad, Rifqi Akuntansi Lembaga Keuangan Publik Islam. Modul Mata Kuliah. Yogyakarta: FIAI UII, 2006.

Mursyidi, Akuntansi Zakat Kontemporer, (Bandung: PT Remaja Rosda Karya, 2003). 
Muslihun, Muslihun. "Dinamisasi Hukum Islam Di Indonesia Pada Zakat Produktif Dan Wakaf Produktif: Sebuah Studi Perbandingan," AlManahij: Jurnal Kajian Hukum Islam 8, no. 2 (January 1, 1970).

Mutia, Agustina. “Analisis Faktor-Faktor yang Mempengaruhi Kesejahteraan Ekonomi Mustahik Melalui Pemberdayaan Zakat (Studi Kasus Penyaluran Zakat Produktif/Modal Usaha pada Bazda Kota Jambi)". KONTEKSTUALITA, 25 (1) 2009.

Pratama, Yoghi Citra. "Peran Zakat Dalam Penanggulangan Kemiskinan (Studi Kasus: Program Zakat Produktif Pada Badan Amil Zakat Nasional)" 1, no. 1 (2015).

Ridwan, Muhammad. Manajemen Baitul Maal Wa Tanwil. Yogyakarta: UII Press, 2006.

Sartika, Mila. "Pengaruh Pendayagunaan Zakat Produktif terhadap Pemberdayaan Mustahiq pada LAZ Yayasan Solo Peduli Surakarta". Jurnal Ekonomi Islam: La_Riba, II (1) 2008.

Zalikha, Siti. "Pendistribusian Zakat Produktif Dalam Perspektif Islam," Jurnal Ilmiah Islam Futura 15, no. 2 (February 1, 2016).

Zalikha, Siti. Pendistribusian Zakat Produktif Dalam Perspektif Islam, (Jurnal Ilmiah Islam Futura, 2016). 